\title{
BCR/ABL1 Fusion Gene with ABL1 NM_005157.4:C.1187A>C Mutation
}

National Cancer Institute

\section{Source}

National Cancer Institute. BCR/ABL1 Fusion Gene with ABL1 NM 005157.4:C.1187A>C

Mutation. NCI Thesaurus. Code C130226.

A fusion gene that results from a translocation $\mathrm{t}(9 ; 22)(\mathrm{q} 34 ; \mathrm{q} 11)$ that fuses the 5 ' part of the $B C R$ gene to the 5 ' side of exon 2 of a mutated form of the ABL1 gene. In this fusion gene there is a point mutation where adenine has been substituted with cytosine at nucleotide position 1187 of the ABL1 gene. 